\title{
STUDY OF FODDER PLANTS OF RUPANDEHI
}

\author{
Anant Gopal Singh \\ Department of Botany, Tribhuvan University, Butwal Multiple Campus, Butwal, Nepal \\ Email: agsingh26@rediffmail.com
}

\begin{abstract}
Fodder, a type of animal feed, is any agricultural food stuff used specifically to feed domesticated livestock. In the present study 37 plant species belonging to 22 families and 26 genera as fodder plants were recorded form different parts of Rupandehi and its surrounding area.
\end{abstract}

Keywords: Fodder plants, livestock, Rupandehi

\section{INTRODUCTION}

Fodder, a type of animal feed, is any agricultural food stuff used specifically to feed domesticated livestock such as cows, buffaloes, goats, sheep, chickens, ducks, pigs etc. Domesticated cattle require feed that gives them energy, proteins, minerals and vitamins to maintain their body condition, milk production, meat production and reproduction. Nepal hosts different agroecological zones which are used to feed large number of livestock. The growth of livestock is less than that of fishery and cash crops. The overall growth rate of livestock is around 5.3 percent per annum (MOAC 2011/12). Livestock is an integral part of the Nepalese farming system, providing cash, food, wool, manure and power. Livestock production is almost solely dependent on those fodder plants and crop residue which are locally available. Plantation of fodder trees and shrubs is an ecologically sound practice, which contributes on soil conservation and maintaining agricultural sustainability.

Fodder trees and shrubs play an important role in Nepalese economy. More than 136 different species of trees and shrubs have been used as a source of livestock feed in Nepal (Bajracharya et al., 1985). Traditionally, foliage fodder tree and shrub have been offered to cattle, buffalo, cow and goats especially in stall-fed condition.
It is estimated that fodder trees and shrubs provide approximately 41 percent of dry matter in annual feed supply (Pandey; 1982). Besides providing fodder to livestock, trees and shrubs also provide fuel wood, poles and timber for house construction (Pande; 2007). Fuel-wood is the major source of the energy needs. It was estimated that fuel wood provides more than 87 percent of the country's energy need (Manandhar; 1980, Danovan; 1981). Trees and shrubs not only provide fodder and fuel wood but also serve as an excellent source for soil improvement and conservation (Brewbaker; 1983).

\section{MATERIALS AND METHODS}

\section{Study Area}

The study was conducted in Rupandehi district $\left(27^{\circ} 20^{\prime}\right.$ to $27^{\circ} 47^{\prime} 25^{\prime \prime} \mathrm{N}$ latitudes and $83^{\circ} 12^{\prime}$ $16^{\prime \prime}$ to $83^{\circ} 38^{\prime} 7^{\prime \prime}$ E longitudes) (Fig. 1). The topographical features of the study area vary greatly from lowlands of south Indian border to the highland Siwalik (Churia) in north.

Rupandehi district occupies the total area of $1360 \mathrm{Km}^{2}$ (CBS, 2011) and is surrounded by Nawalparasi district in the east; Kapilvastu district in the west, hilly district of Palpa and Arghakhanchi in the north and Mahrajganj 
and Siddharthanagar districts of Uttar Pradesh (India) in the south (Figure 1). The study area enjoys a monsoon type of climate with wet summer and dry winter. Maximum percentage of rainfall occurs during the months of June to September. This district is characterized by tropical Sal (Shorea robusta Roth.) forest with tree associates like Sissoo (Dalbergia sissoo Roxb.); Khayar (Acacia catechu (L.f.)Willd.); Saj (Terminalia alata Heyne. ex Roth.); Banjhi (Anogeissus latifolia (Roxb. ex DC.) Wall. ex Bedd.); Simal (Bombax ceiba L.); Jamun (Syzygium cumini (L.) Skeels.) etc. The total population of this district is $8,80,196$ (CBS, 2011). Brahmin, Chhetry, Magar, Tharu, Yadav, Kewat, Gurung, Muslim, Chamar, Newar, Teli, Kurmi, Koiri, Damai, Sunar and Thakuri are the major communities living within the district.

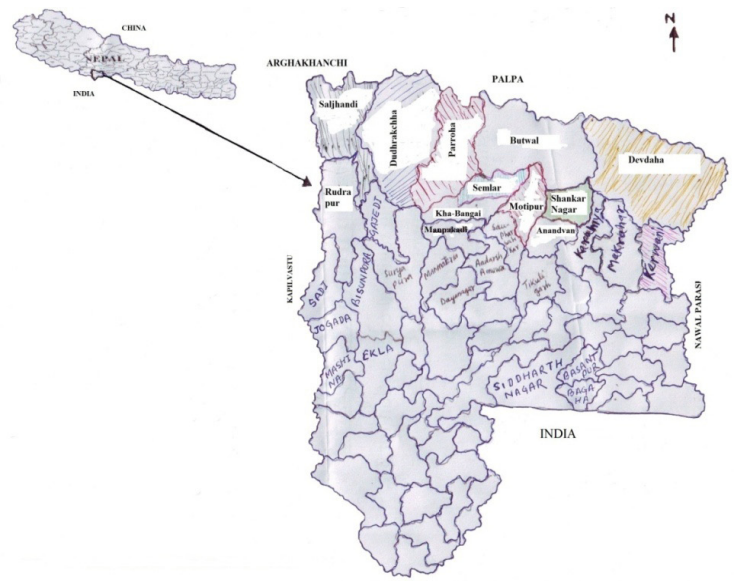

Figure 1: Map of Nepal showing Rupandehi district

\section{Data Collection}

The author visited villages and cities of the Rupandehi district situated near the foot hills of Churia on northern side and Terai region on southern side during 2013 and 2014 and collected data through direct observation of farmer's livestock centers and feeding techniques and through prepared questionnaire. The main objectives of the study was to explore, and identify the plants used by farmers and owners of livestock farming centers as fodder and fuel wood. Following standard technique (Lawrence; 1974) herbarium sheets were prepared and collected plant specimens were identified with the help of floras, books, journal and standard literatures (Polunin and Stainton 1984; Stainton 1988; Grierson and Long $1983-$ 2001; and Noltie, 1994) and nomenclature of the identified plant species follow Hara et al., (1978, 1979, and 1982), and Press et al. (2000). Identification of collected plant specimens were later confirmed by comparing them with authentic specimens available at department of Botany, Tribhuvan University, Butwal Multiple Campus, Butwal and National Herbarium Godavari, Lalitpur, Nepal. The herbaria are deposited at the Department of Botany, Butwal Multiple Campus, Butwal.

\section{RESULT}

In the present study, a total of 37 plant species belonging to 22 families and 26 genera, used as fodder plants, were documented. The documented plant species were arranged alphabetically according to their botanical name (Table 1) 
Table: 1- Collected and identified plant species which are used in feeding livestock

\begin{tabular}{|c|c|c|}
\hline Botanical Name with author citation & Family Name & Local Name \\
\hline Acacia catechu (L.f.) Willd. & Mimosaceae & Khayer \\
\hline Acacia nilotica (L.) Willd. ex Del. & Mimosaceae & Babool \\
\hline Aegle marmelos (L.) Correa & Rutaceae & Bel \\
\hline Albizia lebbek (L.) Benth. & Mimosaceae & Siris \\
\hline Annona squamosa $\mathrm{L}$. & Annonaceae & Sarifa \\
\hline Anogeissus latifolia (Roxb. ex DC.) Wall. ex Bedd. & Combretaceae & Banjhi \\
\hline Anthocephalus cadamba (Roxb.) Miq. & Rubiaceae & Kadam \\
\hline Artemesia vulgaris L. & Asteraceae & Tite pati \\
\hline Artocarpus heterophyllus Lamk. & Moraceae & Katahar \\
\hline Artocarpus lakoocha Roxb. & Moraceae & Badahar \\
\hline Asparagus racemosus Willd. & Asparagaceae & Kurilo \\
\hline Bauhinia purpurea L. & Caesalpinaceae & Tanki \\
\hline Bauhinia variegate $\mathrm{L}$. & Caesalpinaceae & Koiralo \\
\hline Bombax ceiba $\mathrm{L}$. & Bombaceae & Simal \\
\hline Dalbergia sissoo Roxb. Papilionaceae & Papilionaceae & Sisham \\
\hline Ficus auriculata Lour. & Moraceae & Timilo \\
\hline Ficus bengalensis L. & Moraceae & Bar \\
\hline Ficus benjamina L. & Moraceae & Sami \\
\hline Ficus cunia Buch. Ham. ex Roxb. & Moraceae & Khanyu \\
\hline Ficus glomerata Roxb. & Moraceae & Gular \\
\hline Ficus hispida L. & Moraceae & Khasreto \\
\hline Ficus hookerii Miq. & Moraceae & Nevaro \\
\hline Ficus lacor Buch.-Ham. & Moraceae & Kabro \\
\hline Ficus religiosa L. & Moraceae & Pipal \\
\hline Garuga pinnata Roxb. & Burseraceae & Dabdabe \\
\hline Leucaena leucocephala (Lamk.)de Wit & Fabaceae & Epil-epil \\
\hline Litchi chinensis Sonn. & Sapindaceae & Litchi \\
\hline Madhuca longifolia (Koeing) Macbride & Sapotaceae & Mahuwa \\
\hline Mallotus phillippinensis Muell. Arg. & Euphorbiaceae & Sindure \\
\hline Melia azedarach L. & Meliaceae & Bakaino \\
\hline Moringa oleifera Lamk. & Moringaceae & Saijan \\
\hline Morus alba L. & Moraceae & Kimbu \\
\hline Shorea robusta Gaertn. f. & Dipterocarpaceae & Sal \\
\hline Syzygium cumini (L.) Skeels & Myrtaceae & Jamun \\
\hline Terminalia alata Heyne. ex Roth. & Combretaceae & Asna/ Saj \\
\hline Vitex negundo L. & Verbinaceae & Simali \\
\hline Zizhipus mauritiana Lam. & Rhamnaceae & Bayer \\
\hline
\end{tabular}




\section{DISCUSSION AND CONCLUSION}

The present work is totally based on information given by local farmers on the quality of fodder plants. In Rupandehi district and its surrounding areas, farmers lack any scientific knowledge about the fodder, livestock feeding and management. However, they have a good traditional knowledge about the fodder plants and livestock feeding sufficient to keep livestock alive. Farmers usually prefer multipurpose trees or shrubs to cultivate in their fields. They generally cultivate those plants around their houses which are fast growing, having medium height and spreading nature. However, they give more priority to quantity of fodder rather than their quality. In the urban area and villages with pronounced lack of good pasture the hope lies on raising trees and shrubs. Farmers cultivate the plants even in the gardens in place of ornamental plants. A few plants which are used as fodder plants have good food value and farmers cultivated these plants as fodder. These plants are different species of Ficus, Acacia, Artocarpus, and leguminous plants. Providing livestock with nutritious feed and fodder is necessary for maintaining them in a good condition for the economic production of milk, meat and other products. There is considerable lack of information about the fodder resources in Rupandehi district and its surrounding locality. The large bulk of the feed of livestock's is obtained from the crop residue such as hay, straw, dry stalks of crop plants and green or dry grasses. In the lack of adequate alternative source of livestock feed, green fodder consisting of herbage and tree leaves, plays an important role in the nutrition of livestock.

Due to speedy urbanization and lack of land, owners and farmers of livestock farming face a lot of problems in feeding programs. To improve the availability and enhance the use of fodder plants in Nepal for the maintenance of livestock body condition, milk production, meat production, reproduction and other by products, the following actions are recommended,

- Launch fodder shrubs and trees plantation program.

- Convert at least 10 percent of the marginal lands into fodder orchards.

- Cultivate fodder trees or shrubs in grazing land.

- Extend the knowledge of agro-forestry systems in the farming community.

\section{ACKNOWLEDGEMENTS}

The author is grateful to the farmers and owners of livestock farming center of Rupandehi and its surrounding villages for providing valuable information about the fodder plants and feeding technique. I am also thankful to my departmental colleagues for their continuous support and encouragement during writing of manuscript and data compilation.

\section{REFERENCES}

Bajracharya, D., T.B. Bhattarai, M.K. Dhakal, T.N. Mandal, M.R. Sharma, S. Sitaula and B.K. Vimal (1985). Some feed values for fodder plants in Nepal. Angrew Botanik, 59:357-365.

Brewbaker, J.L., (1983). Fodder and fuel wood, $\mathrm{N}$-fixing trees in Nepal. Consultants report for integrated cereal project. Minister of Food and Agriculture, Kathmandu.

Central Bureau of Statistics, (2011). Population census, Government of Nepal, National Planning Commission Secretariat, Central Bureau of Statistics, Nepal.

Danovan, D.G., (1981). Fuel wood, how much do we need? Nepal Forest Technical Information Bulletin-1:26.

Grierson, A.J.C. and D.G. Long, (2001). Flora of Bhutan 1(3), 2 (1-3). Royal Botanic Garden 
Edinburg and Royal Government of Bhutan. Hara, H., A.O. Charter, L.H.J. Williams (1982). An Enumeration of the Flowering Plants of Nepal. Vol. 3. Trustees of British Museum (Natural History) London.

Hara, H., W. T. Stearn, L.H.J. Williams (1978). An Enumeration of the Flowering Plants of Nepal. Vol. 1. Trustees of British Museum (Natural History) London.

Hara, H., L.H.J. Williams (1979). An Enumeration of the Flowering Plants of Nepal. Vol. 2. Trustees of British Museum (Natural History) London.

Lawrence, G. H. M. (1974). Taxonomy of vascular plants, Oxford and IBM, Pub. Co., New Delhi.

Manandhar, P.K. (1980). Introduction to policy, legislation and programs of community forestry Development in Nepal. HMG/ UNDP/FAO Field Document No. 1 Nep/80/030.

Ministry of Agriculture and Cooperatives, (2011/12). Livestock farming System in Nepal. Central Bureau of Statistics, 2011, Kathmandu.
Noltie, H. J. (1994). Flora of Bhutan, Vol III Part I. Royal Botanic Garden, Edinburgh and Royal Government of Bhutan.

Pande, R.S., (2007). Use of Fodder trees and Forest foliage in Nepal. National Forage and Grassland Research Centre, Nepal.

Pandey, K.K., (1982). Fodder trees and tree fodder in Nepal. Swiss Federal Institute of Forestry Research Birmensdorf, Switzerland B 509.

Polunin, O., A. Stainton, (1984). Flowers of the Himalayas. Oxford University Press, London.

Press, J. R., K. K. Shrestha, Sutton, (2000). Annotated Checklist of the Flowering Plants of Nepal. The Natural History Museum London, and Central Department of Botany, Tribhuvan University, Nepal.

Stainton, A. (1997). Flowers of the Himalaya. A Supplement. Oxford University Press, New Delhi, India.

(Received 11 June 2017, revised accepted 13 July 2017) 